\title{
Mesenchymal Stem Cell Transplantation
}

National Cancer Institute

\section{Source}

National Cancer Institute. Mesenchymal Stem Cell Transplantation. NCI Thesaurus. Code C116467.

The transfer of multipotent stromal cells from donor to recipient for the treatment of a variety of different systemic and localized diseases. 